THURSDAY, APRIL 29, 1920.

\section{The Chemical Industries of German Rhineland.}

TN I916, as a result of war conditions, British chemical manufacturers formed an association with the view of strengthening and consolidating their position by mutual help and co-operation. After the declaration of the armistice the association dispatched a Mission to Germany, under the guidance of the Department of Overseas Trade, to study the present position of German chemical industry. The Mission consisted of twenty members of the association, representing various branches of chemical manufacture, and it was accompanied by a military representative and by delegates of the Department of Overseas Trade, the Board of Trade, the Local Government Board, and Canadian interests. Thirty-nine works were visited, all of them in German Rhineland and in zones occupied by the Allies from north of Cologne to Mannheim. The inquiry resolved itself into a study of the position of the following sections of chemical industry, as developed in Germany, viz. (I) Heavy chemicals; (2) coal-tar products, intermediates, and dyestuffs; (3) fine organic and pharmaceutical products; (4) general inorganic products.

The report of the Mission is of the highest public importance, and merits the attentive consideration of every chemical manufacturer in the kingdom. It is, however, too technical to be dealt with here. We are concerned rather with its general purport and with the lessons and warnings it conveys. These are given in the summary of the report which the association has caused to be printed and published. ${ }^{1}$ We trust it will be widely circulated and read. The moral it inculcates is summed up in this one brief sentence: "German chemical industry has been one stupendous organisation for effecting and promoting the application of science to industry"-a statement which, we agree with the writer of the summary, "should be displayed, not only in every office, but in every educational institution in the kingdom," as well as "in all Government Departments."

At the same time, there is nothing very new in this pronouncement. It has been the burthen of innumerable articles and public addresses during the last half-century; and we see their effect in the

1 A Sunmary of the Report of the British Chemical Mission on Chemical Factories in the Occupied Area of Germany. (Association of Bntish Chenical Manufacturers, 166 Piccadilly, W.r.)

$$
\text { NO. } 2635 \text {, VOL. IO5] }
$$

multiplication of our provincial universities and the creation of our various technical colleges and schools. Anyone at all familiar with the history of these institutions knows that their creation has been entirely due to the action of a few publicspirited men who have laboured, in season and out of season, and often under sore discouragement, to effect their establishment. In no single instance have they been due to the spontaneous impulse of a whole community, prompt to recognise and to appreciate the value of science to industry. Even when established, there was, as a rule, no very widespread desire, at all events at the outset, to take advantage of the opportunities they afforded. In most of them their day of small things was a fairly long period.

But the coming of the war brought a great awakening. The national importance of science was recognised as never before. We then realised we were confronted with a nation that had sedulously cultivated science in its application to practically every at $t$ and every industry of peace, as well as of war, and we were amazed and disquieted at our own shortcomings and our supine neglect. The new Education Act is a measure of the degree to which the country has been roused. The ease and practical unanimity with which it was passed are the clearest proofs of the public conviction of its necessity.

The document before us, emanating from a body of experts eminently qualified to express an authoritative opinion, will serve to strengthen that conviction. It deals, of course, mainly with only one branch of applied science; but, as it happens, it has been a branch which has rendered extraordinary service to the country at one of the most critical periods of its history. It was not so much our knowledge of chemistry that helped us, or the facilities we possessed of applying it. In these respects we were lamentably behind our chief enemy, and that enemy knew it. But she reckoned without the national characteristics which ultimately saved the situation, and, luckily for us and the world, her lightning stroke missed its aim, and she was compelled by circumstances to give us time to develop and apply them. But it is safe to say that, had we been capable of taking up the position before the war that we were in at its close, its duration would have been greatly curtailed, and it is conceivable, indeed, that it would never have been begun.

The summary of the report, concise as it is, covers more ground than can be dealt with in a single article. We must therefore confine our- 
selves to a brief statement of the general impressions which the members of the Mission gained concerning the present development of chemical industry in Germany, and its potential future as affected by the war.

To begin with, the Mission was strongly impressed with the evidence of scientific method which appertained to everything relating to the industry, not only to the laboratory and the factory, but also to accountancy, buying and selling, and the management of labour-in fact, to every side of business activity. This result had been achieved by an efficient combination of experts. "The Germans, in fact, have learnt how to use their leaders with utmost effect." It has been the fashion to disparage the originality of the Germans and to point to their lack of inventive power. Whatever may be their failings in these respects, there is no question that it is through their willingness to co-ordinate their efforts that much of their striking success is to be attributed. Moreover, as is pointed out, the chemical industry occupies a high position in Germany, and it can command the services of the best brains in the country. The status of the chemist is such that it is now, at least in the higher positions, one of the best paid of the professions in Germany-far more so than the Law and the Church. How this has been brought about is clearly stated :

"During generations past, unlimited facilities have existed for providing those who wish to become chemists with an education which is nowhere excelled, so that not only is the status of the chemist high, but the man himself, in virtue of his thorough training, is fitted to maintain the high position in which he is placed. Everywhere the chemist is to the fore, and not only are chemists found in the chief administrative positions of the large chemical undertakings, but they frequently control the great organisations characteristic of German industry generally."

The author of the summary has a very definite opinion as to the influence of the German educational system in the universities and the polytechnics in reaching this result, and he contrasts it with our own system of scholarships and bursaries, which he evidently disparages:

"As German education has been carried on without money bribes in the form of scholarships and fellowships, and without competitive examinations, the system has been one of almost complete Lernfreiheit. Although it has often been adversely criticised by those unacquainted with its workings, the results belie all such criticism. At least, the student has always worked with a forward outlook; his effort has been to solve a problem, not merely to acquire knowledge. The system has been as far removed as possible from that pursued in this country, especially at Oxford; there can be little doubt that it has been a factor of great importance in the development of industry on a scientific basis in Germany."

Now, while there is much that is unquestionably true in this statement, in his desire to decry our own educational system the writer has shown either that he himself is not wholly acquainted with the later development of the German system, so far as it is concerned with chemistry and its industrial application, or that he is guilty of a suppressio veri. The German leaders of chemical industry some time ago determined to attract promising chemical students by that very system of "money bribes" which he deprecates, and to endow what are practically fellowships to be held in connection with German university laboratories. In principle there was nothing in this essentially different from our own procedure--except that the aims of the German manufacturers were not quite so altruistic as those of the "pious founders" in our own universities.

The writer of the summary pays a welldeserved compliment to the enterprise, skill, and courage of the men who controlled these vast industrial concerns--their breadth of view and keenness of outlook; their tireless efforts and unfailing perseverance in attacking problems needing years for solution, and for which no early return for the large expenditure involved could be anticipated. Nothing, we are told, appeared to have struck the Mission more than the lavish monetary outlay on laboratories, libraries, and technical staffs. As an example, an account is given of the leading features of the great Bayer works at Leverkusen, one of the most highly organised of the Rhineland factories. We have also a brief statement describing the rapid development of power stations in the Rhine district, especially during the war; and some account of the working of the Interessen Gemeinschaft (I.G.), by which the leading chemical firms co-operate so as to secure community of interests. But limits of space preclude any detailed account of the several matters of interest covered by the report. Enough, however, has been written to indicate its importance. Whilst we cannot wholly subscribe to every statement of the writer of the summary, who has been allowed, possibly, too free a hand in interpreting the findings of the report, we can at least testify that he has the courage of his convictions and little hesitation in giving utterance to them. 